\title{
Differences in risk factors, presentation and angiographic findings in elderly patients with coronary artery disease
}

\author{
Jozica Šikić1,2*, \\ Dario Gulin',2, \\ Ana Marija Slišković ${ }^{3}$, \\ Ante Pašalić', \\ Jasna Čerkez Habek ${ }^{1,4}$
}

'University Hospital "Sveti Duh", Zagreb, Croatia

2University of Zagreb School of Medicine, Zagreb, Croatia

${ }^{3}$ The Croatian Institute of Emergency Medicine, Zagreb, Croatia

${ }^{4}$ Croatian Catholic University, Zagreb, Croatia
RECEIVED:

January 30, 2018

ACCEPTED:

February 10, 2018

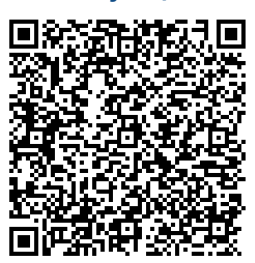

$\square$ Cardiologia Croatica 2018:13(1-2):34.
KEYWORDS: acute coronary syndrome, myocardial infarction, age, elderly.

CITATION: Cardiol Croat. 2018;13(1-2):34. | https://doi.org/10.15836/ccar2018.34

*ADDRESS FOR CORRESPONDENCE: Josica Šikić, Klinička bolnica "Sveti Duh", Sveti Duh 64, HR-10000 Zagreb, Croatia. / Phone: +385-91-3713-023 / E-mail: josicas1@gmail.com

ORCID: Jozica Šikić, https://orcid.org/0000-0003-4488-0559 • Dario Gulin, https://orcid.org/0000-0001-8502-7816 Ana Marija Slišković, https://orcid.org/0000-0001-6622-7572 • Ante Pašalić, https://orcid.org/0000-0001-5989-6495 Jasna Čerkez Habek, https://orcid.org/0000-0003-3177-3797

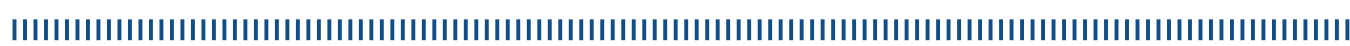

Introduction: Coronary artery disease (CAD) is common among elderly patients and may have certain characteristics that are different from those in younger age..$^{1-3}$ The aim of this study is to determine the presented risk factors, clinical presentation and angiographic findings in elderly patients.

Patients and Methods: This retrospective observational study included all patients referred for coronary angiography at our department in eight-month period. The cutoff of 75 years was used to determine characteristics and outcomes of patients older than 75 years (OP) vs. younger than $75(\mathrm{YP})$.

Results: Among the 942 patients referred for coronary angiography, 178 (18.9\%) were OP. 46 patients (25.8\%) of OP had acute coronary syndrome (ACS) and $22.6 \%$ of YP. Female/male ratio was $46.7 \%$ in OP and $31 \%$ in YP. OP had the higher prevalence of previous myocardial infarction (32\% vs. $24.4 \%$ ) and similar rate of previous PCI (25.8\% vs. $26.7 \%$ ). Cerebrovascular disease was present in 10.1 vs. $6.6 \%$ and peripheral artery disease in 10.1 vs. $7.6 \%$. Previous cardiovascular risk factors were present in OP: smoking $6.7 \%$ vs. $25.7 \%$; hypertension $88.7 \%$ vs. $82.4 \%$; diabetes $30.8 \%$ vs. $26.7 \%$; hyperlipidemia $67.4 \%$ vs. $69.7 \%$. Beta blockers were used in $64.4 \%$, ACE inhibitors in $57.8 \%$ and statins in $45.5 \%$ of OP, while $55.9 \%, 51.1 \%$ and $45.8 \%$ in YP. Mean hospitalization stay was 5.97 days in OP and 5.56 in YP (both median 4 days). Culprit coronary artery was in OP RCA in 39.5\%, LAD in $38.4 \%$ and ACx in $22.1 \%$, while in YP RCA in $35.7 \%$, LAD in $42.6 \%$ and ACX in $21.6 \%$. In OP, type A lesion was present in $10.5 \%$, type B in 57\%, type $\mathrm{C}$ in $15.1 \%$ and coronary occlusion in $17.4 \%$; while in YP $21.2 \%, 51.3 \%, 11.7 \%$ and $15.8 \%$. OP had more coronary segments involved (2.86 vs. 2.57). A median value of percent of luminal stenosis was $99 \%$ in OP and $90 \%$ in YP (mean values - $90.8 \%$ and $85.9 \%$ ). The mean number of stents implanted was higher in OP (0.73 vs. 0.67). GpIIb/IIIa inhibitor was used more in YP (3.9\% vs. 5.3\%).

Discussion and Conclusion: Patients older than 75 show specific group characteristics. This group presented more with ACS, higher female/male ratio, prevalence rates of arterial hypertension, diabetes, previous myocardial infarction, cerebrovascular and peripheral artery disease, and drug intake. More diffused CAD was also observed with more severe types of coronary lesions and higher luminal stenosis.

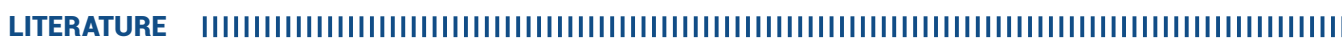

1. Mahjoob MP, Sadeghi S, Khanaman HF, Naderian M, Khaheshi I. Comparison of coronary risk factors and angiographic findings in younger and older patientswith significant coronary artery disease. Rom J Intern Med. 2017 Dec 20. pii: /j/rjim.ahead-of-print/rjim-2017-0048/rjim-20170048.xml. https://doi.org/10.1515/rijm-2017-0048

2. Maroszyńska-Dmoch EM, Wożakowska-Kapłon B. Clinical and angiographic characteristics of coronary artery disease in young adults: a single centre study. Kardiol Pol. 2016;74(4):314-21. https://doi.org/10.5603/KP.a2015.0178

3. Vasiljevic-Pokrajcic Z, Mickovski N, Davidovic G, Asanin M, Stefanovic B, Krljanac G, et al. Sex and age differences and outcomes in acute coronary syndromes. Int J Cardiol. 2016 Aug;217 Suppl:S27-31. https://doi.org/10.1016/j.ijcard.2016.06.217 